Gut, 1983, 24, 231-235

\title{
Effects of bombesin on gastrin and gastric acid secretion in patients with duodenal ulcer*
}

\author{
G DELlE FAVE. ANNA KOHN, LAURA DE MAgistris, B ANNiBAlE, \\ R BRUZZONE. C SPARVOLI. CAROLA SEVERI, AND A TORSOLI
}

From the Cattedra di Gastroenterologia, Clinica Medica II, Università degli Studi di Roma, Policlinico Umberto I. Roma. Italy

SUMmaRY The effect of bombesin, a possible neurotransmitter of gastrin release, upon gastrin and gastric acid secretion was investigated in 25 patients with duodenal ulcer and in 16 normal subjects. In patients with duodenal ulcer bombesin $(10 \mathrm{ng} / \mathrm{kg} / \mathrm{min})$ produced an increase in plasma gastrin output (median 22.4 (range $7 \cdot 5-75 \cdot 8$ ) $\mathrm{pmol} / \mathrm{l} / \mathrm{min}$ ) similar to that obtained in normal subjects (median 24.4 (range $5 \cdot 8-56 \cdot 5) \mathrm{pmol} / \mathrm{l} / \mathrm{min}$ ), whereas gastrin stimulated by a meal was significantly higher in the group of patients with duodenal ulcer (median 20.7 (range $9 \cdot 2-42 \cdot 9$ ) vs $16 \cdot 2$ (range $3 \cdot 4-22 \cdot 2$ ) $\mathrm{p}<0.05$ ). Peak acid output induced by bombesin was significantly higher in patients with duodenal ulcer than in normal subjects (median 24.4 (range $9 \cdot 0-63 \cdot 8$ ) vs 14.0 (range $3 \cdot 0-24 \cdot 8$ ) $\mathrm{mmol} / \mathrm{h}, \mathrm{p}<0 \cdot 05$ ) despite identical gastrin outputs. The ratio (\%) obtained by dividing the acid secretory response to bombesin by the response to pentagastrin, however, was similar in both normal subjects and patients with duodenal ulcer (median 55 (range 20-116) vs 58 (range 31-95) respectively). The difference between the gastrin response to food and bombesin could be explained by the fact that bombesin releases gastrin directly, whereas a protein meal involves several mechanisms (neural, peptidergic, paracrine, endocrine), either stimulatory or inhibitory. The above results indicate that a higher concentration in antral and/or duodenal gastrin is unlikely to be present in patients with duodenal ulcer. An increased parietal cell mass could explain the higher gastric acid response after bombesin infusion in our group of patients with duodenal ulcer.

Conflicting results have been obtained regarding the gastrin response to a protein meal in normal subjects and patients with duodenal ulcer. Several studies have established that total serum gastrin responses to feeding are higher in patients with duodenal ulcer than in normal subjects. ${ }^{1-4}$ while others have failed to show any difference. ${ }^{5}$ Furthermore, previous studies were performed in order to investigate the antral and duodenal content of gastrin in both normal subjects and patients with duodenal ulcer. ${ }^{78}$ Creutzfeldt $e t \mathrm{al}^{7}$ found increased gastrin stores in patients with duodenal ulcer, while Malmstrom et

\footnotetext{
* A preliminary report of this work has been published in abstract form (Regulatory Peptides 1980: 1: S 24).

Address for correspondence: Dr Gianfranco Delle Fave. Cattedra di Gastroenterologia. Clinica Medica II. Policlinico Umberto I. 00161 Roma. Italy.

Received for publication 1 June 1982
}

$a l^{8}$ found no difference between normal subjects and patients with duodenal ulcer.

The tetradecapeptide bombesin, isolated by Erspamer from the skin of the European frog Bombina bombina, ${ }^{9}$ is the only peptide known to induce endogenous gastrin release ${ }^{11} 11$ its action is particularly marked and a direct mechanism has been suggested. ${ }^{12} 13$ Bombesin has also been proposed as the possible neurotransmitter of gastrin release. ${ }^{14}$ In normal subjects bombesin induces a greater gastrin response than food. ${ }^{10}$ In the present investigation we infused bombesin to see if a different gastrin release was present between patients with duodenal ulcer and normal subjects. Bombesin-induced gastrin release was compared with that produced by a physiological stimulus such as a protein meal. In addition we studied the effect of intravenous bombesin on gastric acid secretion. 


\section{Methods}

SUBJECTS

Studies were performed on 25 patients with active duodenal ulcer, 16 men and nine women (mean age 40 years, 25 to 60 years), and 16 healthy volunteers, 10 men and six women (mean age 38 years, 21 to 55 years). The study was approved by the Clinical Research Committee of Clinica Medica II of the Rome University on 13 November 1979; and informed consent was obtained from each patient. Diagnosis of duodenal ulcer was based upon clinical and endoscopic findings. All the patients were on antacid therapy which they were allowed to take up to the night before each of the three studies. On three different days all individuals underwent three different studies: (1) bombesin to stimulate gastrin and gastric acid secretion; (2) standard meal to stimulate gastrin; (3) pentagastrin to stimulate gastric acid secretion. The studies were carried out in randomised order at intervals of at least four days.

Bombesin (synthetic tetradecapeptide. Farmitalia, Milano) was intravenously infused for 30) minutes by means of a Harvard syringe pump (Harvard Apparatus Co, Millis, Mass) at the constant rate of $10 \mathrm{ng} / \mathrm{kg} / \mathrm{min}$, which is the maximal gastrin stimulating dose of bombesin. ${ }^{12}{ }^{13}$ Pentagastrin (Gastrodiagnost, Merck) was administered subcutaneously in a dose of $6 \mu \mathrm{g} / \mathrm{kg}$. After an overnight fast a 14 French Levine with a radioopaque tip was positioned under fluoroscopic control with the tip in the gastric antrum. The gastric content was completely aspirated and discarded. Basal and stimulated gastric acid secretion was collected by means of a pump with intermittent negative pressure (Gastrovac 100). Acid secretion was collected for a 30 minute basal period under continuous intravenous infusion of saline and for 90 minutes after pentagastrin administration and after bombesin infusion. Collections were made at 15 minute intervals and titrated to $\mathrm{pH} 7.0$ (PHM 62 Radiometer, Copenhagen) with $0 \cdot 1 \mathrm{M} \mathrm{NaOH}$. Bile contaminated samples (less than $15 \%$ ) were discarded. Blood samples for gastrin determination were obtained through an indwelling 19-gauge scalp-vein needle from a forearm vein, collected in EDTA plus aprotinin and immediately refrigerated. Plasma was separated by centrifugation and stored at $-20^{\circ} \mathrm{C}$ until assayed.

\section{Gastrin assay}

Plasma gastrin levels were determined by radioimmunoassay as previously described, ${ }^{10}$ using antiserum 2604 (kindly supplied by Professor J F Rehfeld) which measures the sulphated and unsulphated forms of gastrin components I, II, III with almost equimolar potency. ${ }^{15}$ No interference by bombesin was shown in gastrin radioimmunoassay at the molar concentrations used in the present study. Plasma values are expressed as pmol/l equivalent of SHG 17 I.

\section{Calculations}

(iastrin output is expressed as the integrated gastrin response (IGR). I(jR wals calculated by means of the following formula:

$$
\begin{aligned}
& \text { IGR }= \\
& \frac{\Delta G_{01}+\Delta G_{1}}{2} \times\left(t_{1}-t_{11}\right)+\frac{\Delta G_{1}+\Delta G_{2}}{2} \times\left(t_{2}-t_{1}\right) \\
& \quad+\frac{\Delta G_{n-1}+\Delta G_{n 1}}{2} \times\left(t_{n}-t_{n}\right) \times \frac{1}{t_{n}-t_{11}}
\end{aligned}
$$

$\Delta \mathrm{G}$ is plasma gastrin concentration minus basal gastrin concentration; $t$ is time in minutes; subscripts 0. 1. $2 \ldots \ldots$ refer to successive sampling periods $\left(0=\right.$ basal sample so $\Delta G_{0}$ is always equal to zero). Gastric acid secretion was calculated as peak acid output (PAO $\mathrm{mEq} / \mathrm{h})$. Results are expressed as median plus range values.

As the distribution of the data was skew, the statistical analysis of the results was obtained by means of the Mann-Whitney test, and the Spearman test. A p value less than 5\% was accepted.

\section{Results}

Gastrin levels promptly increased under bombesin infusion in both groups. The maximal gastrin increment did not significantly differ between normal subjects and patients with duodenal ulcer (median 63.5 (range 20.4-107.6) and 52.8 (range 16.2-144.5) $\mathrm{pmol} / \mathrm{l}$ respectively; data not shown). A protein meal produced a sustained gastrin response which was significantly higher in patients with duodenal ulcer than in controls: (median 21.7 (range 9.2-42.9) vs $16 \cdot 2$ (range $3.4-28 \cdot 2$ ) $\mathrm{pmol} / \mathrm{l} / \mathrm{min}$ ), $\mathrm{p}<0.05$. The rate of gastrin output induced by bombesin was similar in both groups, so that normal subjects showed a bombesin-stimulated gastrin output significantly higher than that induced by meal (median 24.4 (range 5.8-56.5) vs 16.2 (range 3.4$28.2) \mathrm{pmol} / \mathrm{l} / \mathrm{min}, \mathrm{p}<0.05)$, whereas in patients with duodenal ulcer no significant difference was observed between the gastrin output induced by meal and bombesin (Table).

No correlation was observed between the gastrin responses to bombesin and to protein meal in both groups (Fig. 1).

Pentagastrin-stimulated gastric acid secretion was higher than bombesin-induced acid response both in normal subjects (median 20.8 (range 7.8-36.7) vs 
Table Gastrin response to bombesin $(10 \mathrm{ng} / \mathrm{kg} / \mathrm{min}$ ) and to protein meal in normal subjects ( $(\mathrm{V})$ and patients with duodenal ulcer (DU) (median plus range)

\begin{tabular}{|c|c|c|c|c|c|c|c|c|}
\hline & \multicolumn{4}{|l|}{ Meal } & \multicolumn{4}{|c|}{ Bombesin } \\
\hline & \multicolumn{2}{|l|}{$N$} & \multicolumn{2}{|l|}{$D U$} & \multicolumn{2}{|l|}{$N$} & \multicolumn{2}{|l|}{$D U$} \\
\hline & Median & Range & Median & Range & Median & Range & Median & Range \\
\hline Gastrin output (pmol/l/min) & $L^{16 \cdot 2}$ & $\begin{array}{c}(3 \cdot 4-28 \cdot 2) \\
-p<0.05\end{array}$ & 21.7 & $(9 \cdot 2-42 \cdot 9)$ & $24 \cdot 4$ & $\begin{array}{r}(5 \cdot 8-56 \cdot 5) \\
-p>0 .(15)\end{array}$ & $22 \cdot 4$ & $(7 \cdot 5-75 \cdot 8)$ \\
\hline
\end{tabular}

14.0 (range $3 \cdot 0-24 \cdot 8$ ) $\mathrm{mmol} / \mathrm{h}, \mathrm{p}<0.05$ ) or in patients with duodenal ulcer (median $40 \cdot 3$ (range $20 \cdot 8-80 \cdot 0$ ) vs 24.4 (range $9 \cdot 0-63 \cdot 8$ ) $\mathrm{mmol} / \mathrm{h}$, $\mathrm{p}<0.01$ ). Like pentagastrin, bombesin induced a significantly higher gastric peak acid output in patients with duodenal ulcer than in normal subjects (median 24.4 (range 9.0-63.8) vs 14.0 (range 3.0 $24.8) \mathrm{mmol} / \mathrm{h}, \mathrm{p}<0 \cdot 01$ ). (Fig. 2).

The ratio (\%) obtained, however, by dividing the acid secretory response to bombesin by the response to pentagastrin was similar both in normal subjects and patients with duodenal ulcer (median 55 (range 20-116) and 58 (range 31-95)). (Fig. 2).

\section{Discussion}

It has been reported that, after eating, the gastrin

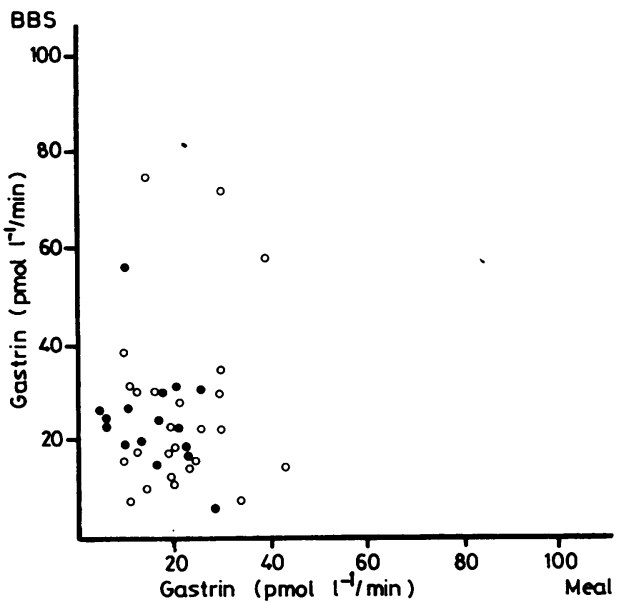

Fig. 1 Correlation between gastrin output (pmol/l/min) stimulated by either meal or bombesin in normal subjects $(\bullet)(r=0.2822)$ and patients with duodenal ulcer $(0)$ $(r=0 \cdot 3056)(p>0 \cdot 1)$. response in patients with duodenal ulcer is higher than in normal subjects. ${ }^{1-4}$ Our study confirms these data. In normal subjects the infused amphibian polypeptide, bombesin, produced a greater gastrin release than food. In patients with duodenal ulcer. gastrin release did not differ either with bombesin or food. Furthermore, the gastrin response to bombesin was similar in both groups. These results strongly support those studies which have not shown any consistent differences in tissue gastrin content between normal subjects and patients with duodenal ulcer. $^{8}$

The consumption of food involves several mechanisms (neural, peptidergic, paracrine, endocrine $)^{16}$ which control gastrin release. As bombesin acts directly on gastrin release, ${ }^{12}{ }^{1.3}$ these different mechanisms could explain our results. In

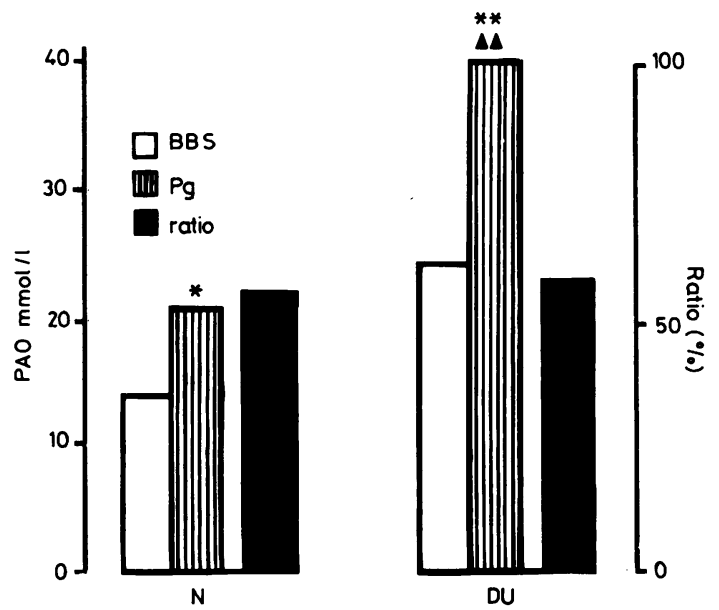

Fig. 2 Gastric acid secretory response to bombesin (10 $\mathrm{ng} / \mathrm{kg} / \mathrm{min})$ and to pentagastrin $(6 \mu \mathrm{g} / \mathrm{kg})$ in normal subjects $(N)$ and patients with duodenal ulcer $(D U)$, expressed as $P A O$ (mmol/h of $\mathrm{H}^{+}$; median values). Ratio was calculated as follows: $B B S-P A O / P g-P A O \times 100{ }^{*} B B S$ vs $P g$ in $N$, $p<0.05 ;{ }^{* *} B B S$ vs $P g$ in $D U, p<0.01 ; \triangle B B S$ in $N$ vs $B B S$ in $D U, p<0.01 ; \triangle \triangle P g$ in $N$ vs $P g$ in $D U, p<0.01$. 
fact, no correlation exists between meal and bombesin-induced gastrin outputs in both groups.

Although we did not evaluate the gastrin content in the antrum and duodenum, inconclusive data have been obtained up to the present time. ${ }^{7 \times}$ Furthermore, in order to ensure that the above determinations are reliable they should be performed only on surgical specimens; this, of course, was impossible in our study. The gastrin response to bombesin is, however, dose-related ${ }^{12} 1.3$ and it is likely that this response could be correlated with the tissue content: in fact, we infused the maximal gastrin-stimulating dose of bombesin. ${ }^{13}$ Thus the differential response to food of our group of patients with duodenal ulcer, compared with normal subjects, does not depend on different gastrin stores. Some hypotheses can be made: bombesin might release different molecular forms of gastrin, in comparison with food, and G cells might be more sensitive to a protein meal, in our group of patients with duodenal ulcer.

It is well known that patients with duodenal ulcer have a higher acid response to pentagastrin than normal subjects: ${ }^{17}$ our results of gastric acid secretion confirm these data. This secretory pattern occurs even with intravenous bombesin, despite similar gastrin outputs. Bombesin stimulates gastric acid secretion less than pentagastrin in normal subjects. ${ }^{10}$ Our data show that even in patients with duodenal ulcer bombesin is less potent than pentagastrin. These results do not confirm those reported by others, ${ }^{18}$ who showed in eight patients with duodenal ulcer similar acid secretory responses after bombesin and pentagastrin. The discrepancy could be explained either by the different method of drug administration, and the different dose of bombesin used, or by the small and selected number of patients studied. The different secretory response to bombesin between normal subjects and patients with duodenal ulcer, the gastrin response being identical, is likely to be because of an increased secretory rate in our group of patients with duodenal ulcer. In fact, if we express the gastric acid response to bombesin as the percentage of the acid response to pentagastrin, no difference is found in both groups.

An increased parietal cell mass has been reported in patients with duodenal ulcer. ${ }^{19}{ }^{20}$ In our opinion these results can be explained by the abovementioned studies. An increased parietal cell sensitivity to endogenous gastrin, however, cannot be excluded.

Finally, bombesin has been found in the gastric mucosa of mammals, including man. ${ }^{21}$ Therefore, it is possible that bombesin might play a physiological role in basal and food-stimulated gastrin release in man. Moreover, it has been suggested that in patients with duodenal ulcer the antral content of bombesin is higher than in normal subjects. ${ }^{22}$ Further studies are needed, however, to elucidate the importance of bombesin in human physiology.

The authors wish to thank Professor V Erspamer for his constructive criticism and Dr P Olivotto for help with the statistical analysis. Bombesin was kindly supplied by Dr R De Castiglione (Farmitalia, Italy). Gastrin antiserum was a generous gift from Professor J F Rehfeld (Aarhus, Denmark). The study was supported in part by grant no. 79.01988.(1)4 from the National Research Council of Italy (CNR), and by a grant from Smith Kline and French (Italy).

\section{References}

1 Fritsch WP, Hausamen TU, Rick W. Gastric and extragastric gastrin release in normal subjects, in duodenal ulcer patients, and in patients with partial gastrectomy (Billroth I). Gastroenterology 1976; 71: 552-7.

2 Stern DH. Walsh JH. Gastrin release in post-operative ulcer patients: evidence for release of duodenal gastrin. Gastroenterology 1971; 64: 363-9.

3 Thompson JC, Reeder DD, Buncham HA. Effect of secretin on circulating gastrin. Ann Surg 1972; 176: 384-91.

4 Byrnes DL, Lam SK, Sircus W. The relation between functioning parietal cell and cell masses in two groups of duodenal ulcer patients. Clin Sci Mol Med 1976; 50: 375-83.

5 Lam SK, Isemberg JI, Grossman MI. Lane WH, Walsh JH. Gastric acid secretion is abnormally sensitive to endogenous gastrin released after peptone test meals in duodenal ulcer patients. J Clin Invest 1980; 65: 555-62.

6 Reeder DD, Jackson BM, Ban JL, Davidson WD. Thompson JC. Effect of food on serum gastrin concentrations in duodenal ulcer and control patients. Surg Forum 1970; 21: 290-1.

7 Creutzefeldt W, Arnold R, Creutzefeldt C, Track NS. Mucosal gastrin concentration, molecular forms of gastrin, number and ultrastructure of $\mathrm{G}$ cells in patients with duodenal ulcer. Gut 1976; 17: 745-54.

8 Malmstrom J, Stadil F, Rehfeld JF. Concentration and component pattern in gastric, duodenal and jejunal mucosa of normal human subjects and patients with duodenal ulcer. Gastroenterology 1976; 70: 697-703.

9 Anastasi A, Erspamer V, Bucci M. Isolation and structure of bombesin and alytesin. two analogous active peptides from the skin of the European Amphibians Bombina and Alytes. Experientia 1971; 27: $166-7$.

10 Delle Fave G, Kohn A, de Magistris L. Mancuso M. Sparvoli C. Effect of bombesin-stimulated gastrin on 
gastric acid secretion in man. Life Sci 198(): 27: 993-9.

11 Bertaccini G. Erspamer V. Melchiorri P. Sopranzi N. Gastrin release by hombesin in the dog. $\mathrm{Br} J$ Pharmacol 1974: 52: 219-25.

12 Varner AA. Modlin IM. Walsh JH. High potency of bombesin for stimulation of human gastrin release and gastric acid secretion. Regulatory Peptides 1981: 1: 289-96.

13 Bruzzone R. Annibale B. Severi C. et al. Role of bombesin on gastric acid secretion in man. International Symposium on Brain-Gut Axis, Florence. 29-30) June. 1 July 1981.

14 Grossman MI. Vagal stimulation and inhibition of acid secretion and gastrin release: which aspects are cholinergic!' In: Rehfeld JF. Amdrup E. eds. Gastrin and vagus. London: Academic Press, 1979: 105-13.

15 de Magistris L. Rehfeld JF. A simple enzymatic procedure for radioimmunochemical quantification of the large molecular forms of gastrin and cholecystokinin. Anal Biochem 198(): 102: 126-33.
16 Polak JM. Bloom SR. The neuropeptides and the antrum. In: Rehfeld JF. Amdrup E. eds. Gastrin and l'agus. London: Academic Press. 1979: 15-30.

17 Isemberg JI. Gastric secretory testing. In: Sleisenger MM. Fordtran JS, eds. Gastrointestinal disease. Philadelphia: Saunders, 1978: 714-32.

18 Kisfalvi I. Inhibition of bombesin-stimulated gastric acid-secretion by secretin, glucagon and caerulein in patients with duodenal ulcer. Digestion 1979; 19: 315-21.

19 Cox AJ. Stomach size and its relation to chronic peptic ulcer. Arch Pathol 1952; 54: 407.

2) Marks IN. Shay H. Observation on the pathogenesis of gastric ulcer. Lancet 1959; 1: 1107.

21 Polak JM. Bloom SR. Hobbs MA. Solcia F. Pearse AGE. Distribution of a bombesin-like peptide in human gastrointestinal tract. Lancet 1976; 1: 1109-12.

22 Baron JH. Pathophysiology of duodenal ulcer. In: Bloom SR, ed. Gut hormones. London: Churchill Livingstone, 1978: 613-9. 